\title{
Analisis Risiko Pembiayaan Bank Syariah
}

\author{
Rahmat Ilyas \\ IAIN Syaikh Abdurrahman Siddik Bangka Belitung \\ mtd_82@yahoo.com
}

\begin{abstract}
Financing is funding provided by one party to another party to support the planned investment, whether done alone or in an institution. Risk in the banking context is a potential event, both predictable and unpredictable that has a negative impact on bank income and capital. The main reason for the occurrence of credit risk is that banks are too easy to lend or invest because they are too required to take advantage of excess liquidity, so that credit assessments are less careful in anticipating various possible business risks that they finance. Risk management is needed to identify, measure and control various types of risk, because it becomes a very basic tool to support the sustainability of the bank's business. The type of risk management that is closely related to the role of DPS is reputation risk, which in turn has an impact on displaced commercial risk, such as liquidity risk and other risks. The function and role of DPS in Islamic banks has strong relevance to the risk management of Islamic banking, namely reputation risk, which in turn impacts other risks such as liquidity risk.
\end{abstract}

Keywords: Risk, Financing, DPS

\begin{abstract}
Abstrak
Pembiayaan merupakan pendanaan yang diberikan oleh suatu pihak kepada pihak lain untuk mendukung investasi yang telah direncanakan, baik dilakukan sendiri maupun lembaga. Risiko dalam konteks perbankan merupakan suatu kejadian potensial, baik yang dapat diperkirakan maupun yang tidak dapat diperkirakan yang berdampak negatif terhadap pendapatan dan permodalan bank. Penyebab utama terjadinya risiko kredit adalah terlalu mudahnya bank memberikan pinjaman atau melakukan investasi karena terlalu dituntut untuk memanfaatkan kelebihan likuiditas, sehingga penilaian kredit kurang cermat dalam mengantisipasi berbagai kemungkinan risiko usaha yang dibiayainya. Manajemen risiko dibutuhkan untuk mengidentifikasi, mengukur, dan mengendalikan berbagai macam risiko, karena itu menjadi alat yang sangat mendasar untuk mendukung keberlangsungan usaha bank. Jenis manajemen risiko yang terkait erat dengan peran DPS adalah risiko reputasi yang selanjutnya berdampak pada displaced commercial risk, seperti risiko likuiditas dan risiko lainnya. Fungsi dan peran DPS di bank Islam memiliki relevansi yang kuat dengan manajemen risiko perbankan Islam, yakni risiko reputasi, yang selanjutnya berdampak pada risiko lainnya seperti risiko likuiditas.
\end{abstract}

Kata Kunci: Risiko, Pembiayaan, DPS

\section{PENDAHULUAN}

Bank Islam atau yang biasa disebut bank syariah merupakan bank yang beroperasi dengan tidak mengandalkan kepada sistem bunga, akan tetapi bank Islam atau yang disebut juga dengan bank tanpa bunga adalah lembaga 
keuangan atau perbankan yang operasional dan produknya dikembangkan berdasarkan al-qur'an dan hadits (Karnaen Perwataatmadja dan Muhammad Syafii Antonio, 1992:1). dengan kata lain bank syariah adalah lembaga keuangan yang usaha pokoknya memberikan pembiayaan dan jasa-jasa lainnya dalam lalu lintas pembayaran serta peredaran uang yang pengoperasiannya disesuaikan dengan prinsip syariat Islam. (Muhammad, 2005a). Bank sebagai lembaga perantara jasa keuangan (financial intermediary) yang tugas pokoknya adalah menghimpun dana dari masyarakat, diharapkan dengan dana dimaksud dapat memenuhi kebutuhan dana pembiayaan yang tidak disediakan oleh dua lembaga sebelumnya baik lembaga negara mapun swasta.

Hadirnya bank syariah dewasa ini menunjukkan kecenderungan yang semakin baik. produk-produk yang dikeluarkan bank syariah cukup variatif, sehingga mampu memberikan pilihan atau alternatif bagi calon nasabah dalam memanfaatkannya. produk unggulan dan produk khas bank syariah tersebut adalah al-musyarakah dan al-mudharabah.

Bank syariah merupakan salah satu instrumen yang digunakan untuk menegakkan aturan-aturan ekonomi islami. Sebagai bagian dari sistem ekonomi, lembaga tersebut merupakan bagian dari keseluruhan sistem sosial. Oleh karenanya, keberadaannya harus dipandang dalam konteks keseluruhan keberadaan masyarakat, serta nilai-nilai yang berlaku dalam masyarakat yang bersangkutan (Muhammad, 2009: 2).

\section{KAJIAN LITERATUR}

\section{Pembiayaan Bank Syariah}

Dalam masyarakat Indonesia, selain dikenal istilah utang piutang juga dikenal istilah kredit dalam perbankan konvensional dan istilah Pembiayaan dalam perbankan syariah. Utang piutang biasanya digunakan oleh masyarakat dalam konteks pemberian pinjaman pada pihak lain. Seseorang yang meminjamkan hartanya pada orang lain maka ia dapat disebut telah memberikan utang padanya. Sedangkan istilah kredit atau pembiayaan lebih banyak digunakan oleh masyarakat pada transaksi perbankan dan pembelian yang tidak dibayar secara tunai. Secara esensial, antara utang dan kredit atau pembiyaan tidak jauh beda dalam pemaknaannya di masyarakat.

Pembiayaan selalu berkaitan dengan aktivitas bisnis. untuk itu, sebelum kita masuk kepada masalah pengertian pembiayaan, perlu kita ketahui apa itu bisnis. Bisnis adalah aktivitas yang mengarah kepada peningkatan nilai tambah melalui proses penyerahan jasa, pedagangan atau pengolahan barang (produksi). dengan kata lain, bisnis merupakan aktivitas berupa pengembangan aktivitas ekonomi dalam bidang jasa, perdagangan dan industri guna mengoptimalkan nilai keuntungan (Muhammad, 2005b: 17).

Pembiayaan atau financing ialah pendanaan yang diberikan oleh suatu pihak kepada pihak lain untuk mendukung untuk investasi yang telah direncanakan, baik dilakukan sendiri maupun lembaga. dengan kata lain, 
pembiayaan adalah pendanaan yang dikeluarkan untuk mendukung investasi yang telah direncanakan (Muhammad, 2005b: 17).

Dalam Undang-undang Nomor 10 tahun 1998 disebutkan bahwa pembiayaan berdasarkan prinsip syariah yaitu penyediaan uang atau tagihan yang dipersamakan dengan itu berdasarkan persetujuan atau kesepakatan antara bank dengan pihak lain yang mewajibkan pihak yang dibiayai untuk mengembalikan uang atau tagihan tersebut setelah jangka waktu tertentu dengan imbalan atau bagi hasil (Undang-undang No. 10 Tahun 1998).

Istilah pembiayaan pada intinya berarti I believe, I Trust, 'saya percaya' atau 'saya menaruh kepercayaan'. Perkataan pembiayaan yang berarti (trust), berarti lembaga pembiayaan selaku shahibul mal menaruh kepercayaan kepada seseorang untuk melaksanakan amanah yang diberikan. Dana tersebut harus digunakan dengan benar, adil, dan harus disertai dengan ikatan dan syarat-syarat yang jelas dan saling menguntungkan bagi kedua belah pihak (Veithzal Rivai dan Andria Permata Veithzal, 2008: 3).

Pembiyaan dalam bank syariah di wujudkan dalam bentuk pembiayaan aktiva produktif dan aktiva tidak produktif. Adapun jenis pembiayaan yang dimaksud yaitu sebagai berikut:

1. Pembiayaan yang bersifat aktiva produktif yaitu Pembiayaan dengan prinsip bagi hasil. Untuk jenis pembiayaan dengan prinsip bagi hasil meliputi:

a. Pembiayaan Mudharabah

Pembiayaan Mudharabah murapakan akad bagi hasil ketika pemilik dana/modal atau biasa disebut shahibul mal menyediakan modal (100 persen) kepada pengusaha sebagai pengelola atau biasa disebut mudharib, untuk melakukan aktivitas produktif dengan syarat bahwa keuntungan yang dihasilkan akan dibagi diantara mereka menurut kesepakatan yang ditentukan sebelumnya dalam akad. (Ascarya, 2011: 60). Ada dua tipe pembiyaan Mudharabah, yakni: Pertama, Mudharabah mutlaqah : pemilik dana memberikan keleluasaan penuh kepada pengelola untuk menggunakan dana tersebut dalam usaha yang dianggapnya baik dan menguntungkan. Pengelola bertanggungjawab untuk mengelola usaha sesuai dengan praktekkebiasaan usaha normal yang sehat (uruf). Kedua, Mudharabah muqayyadah: pemilik dana menentukan syarat dan pembatasan kepada penegelola dalam penggunaan dana tersebut dengan jangka waktu, tempat, jenis usaha dan sebagainya. Pengelola menggunakan modal tersebut dengan tujuan yang dinyatakan secara khusus, yaitu untuk menghasilkan keuntungan. (Zainul Arifin , 2006: 19).

b. Pembiayaan Musyarakah

Pembiayaan musyarakah adalah suatu perjanjian usaha antara 2 atau beberapa pemilik modal untuk menyertakan modalnya pada suatu proyek, dimana masing-masing pihak mempunyai hak untuk ikut serta, mewakilkan atau menggugurkan haknya dalam manajemen proyek. Keuntungan dari hasil usaha bersama ini dapat dibagikan baik menurut 
proporsi penyertaan modal masing-masing maupun sesuai dengan kesepakatan bersama (unproportional). Mnakala merugi kewajiban hanya terbatas sampai batas modal masing-masing. (Karnaen Perwataatmadja dan Muhammad Syafii Antonio, 1992: 23).

c. Pembiayaan dengan prinsip jual beli

Prinsip jual beli dilaksanakan sehubungan dengan adanya perpindahan kepemilikan barang atau benda (transfer of property). Tingkat keuntungan bank ditentukan didepan dan menjadi bagian atas barang yang dijual. (Adiwarman karim, 2006: 98).

d. Pembiayaan dengan prinsip sewa

Transaksi Ijarah (sewa) dilandasi adanya pemindahan manfaat. Jadi pada dasrnya ijarah sama denga prinsip jual beli, tapi perbedaannya terletak pada objek transaksinya. Bila pada jual beli objek transaksinya adalah barang, pada ijarah objek transaksinya adalah jasa. (Adiwarman karim, 2006: 98).

2. Pembiyaan yang bersifat aktiva tidak produktif

Jenis aktiva produktif yang berkaitan dengan aktivitas pembiayaan adalah berbentuk pinjaman, yaitu:

a. Pinjaman Qardh

Pinjaman qardh atau talangan adalah penyediaan dana atau tagihan antara bank Islam dengan pihak peminjam yang mewajibkan pihak peminjam melakukan pembayaran sekaligus atau secara cicilan dalam jangka waktu tertentu. Aplikasi qardh dalam perbankan biasanya dalam empat hal, yaitu:

1) Sebagai pinjaman talangan haji, dimana nasabah calon haji diberikan pinjaman talangan untuk memenuhi syarat penyetoran biaya perjalanan haji. Nasabah akan melunasinya sebelum keberangkatan haji.

2) Sebagai pinjaman tunai dari produk kartu kredit syariah, dimana nasabah diberi keleluasaan untuk menarik uang tunai milik bank melalui ATM. Nasabah akan mengembalikannya sesuai waktu yang ditentukan.

3) Sebagai pinjaman kepada pengusaha kecil, dimana menurut perhitungan bank akan memberatkan sipengusaha bila diberikan pembiayaan dengan skema jual beli, atau bagi hasil.

4) Sebagai pinjaman kepada pengurus bank, dimana bank menyediakan fasilitas ini untuk memastikan terpenuhinya kebutuhan pengurus bank. Pengurus akan mengembalikan dana pinjaman itu secara cicilan melalui pemotongan gajinya. (Adiwarman karim, 2006: 106).

\section{Pengertian Risiko}

Dalam aktivitas-aktivitas yang melibatkan masa depan, ketidakpastian itu melekat. Risiko dapat didefenisikan sebagai "keberadaan ketidakpastian tentang hasil di masa mendatang", namun suatu pembedaan dapat dilakukan antara konsep risiko menurut metafisika dan konsep risiko menurut 
epistimologi. Ciri risiko menurut metafisika adalah "suatu realitas yang ada dengan sendirinya di dunia" dan konsep risiko menurut epistomologi adalah "penilaian yang dibuat oleh seseorang atau aplikasi pengetahuan tertentu tentang ketidakpastian. (Isra, 2015: 663).

Risiko berkaitan dengan kasus-kasus ketika probabbilitas objektif atau probabilitas subjektif dapat ditentukan pada hasil potensial, sehingga memungkinkan untuk kuantifikasi. Ketidakpastian merujuk pada kasus ketidaktahuan secara penuh tentang hasil apapun yang potensial terjadi, sehingga membuat tidak mungkin dilakukan kuantifikasi maupu pengambilan keputusan yang rasional. Implikasinya adalah pada kasus risiko, hal yang tidak diketahui dapat secara potensial dikendalikan dengan menerapkan pengetahuan yang tepat. Pada ketidakpastian, hal yang tidak diketahui bersifat acak dan tidak dapat diprediksi atau tidak dapat dikendalikan.

Dalam ilmu ekonomi dan keuangan, risiko diklasifikasikan dalam beragam cara. Salah satunya adalah dengan membedakan antara risiko bisnis dan risiko keuangan. Risiko bisnis disebabkan oleh ketidakpastian yang timbul dari sifat bisnis suatu firma. Risiko bisnis berkaitan dengan faktor-faktor yang mempengaruhi produk pasar. Risiko keuangan adalah ketidakpastian yang timbul dari kemungkinan merugi pada pasar keuangan akibat pergerakan berbagai variabel keuangan. (Isra, 2015: 663).

\section{Jenis-jenis Risiko Bank Syariah}

Perspektif luas tentang risiko dan pengelolaannya terjelma dalam keseluruhan tujuan hukum Islam atau maqashid al-syariah. Dalam mendefenisikan maqashid Chapra mengutip al-Ghazali yaitu menggiatkan "kesejahteraan umat manusia yang terletak pada perlindungan iman (din), jiwa (nafs), akal (aql), keturunan (nasl), dan harta (mal)". Prinsip maqashid mengimplisitkan mengambil semua langkah pencegahan untuk melindungi kekayaan saat ini dan kekayaan mendatang. Dalam ilmu ekonomi, karena risiko menggambarkan kemungkinan kehilangan kekayaan, maka dengan sendirinya dari perspektif Islam risiko tidaklah diharapkan. Risiko-risiko dengan sendirinya tidak diharapkan, namun risiko-risiko harus diusahakan guna menciptakan kekayaan dan nilai. Dari perspektif Islam, aktivitasaktivitas ekonomi tidaklah diputuskan menurut risiko-risikonya yang inheren, melainkan menurut apakah aktivitas-aktivitas ekonomi tersebut menambah nilai dan atau menciptakan kekayaan. (Isra, 2015: 666).

Sejalan dengan bahasan diatas Hassan mengidentifikasi tiga tipe risiko dari perspektif Islam:

Pertama, risiko esensial yang inheren di dalam semua transaksi bisnis. Risiko bisnis tipe ini diperlukan dan harus diusahakan untuk menghasilkan penghargaan atau laba. Dua kaidah hukum yang mengasosiasikan imbalan dengan risiko esensial membentuk basis transaksi - transaksi ekonomi syariah. Kaidah pertama menyatakan: "kerugian adalah imbalan atas manfaat yang didapatkan (al-ghunm bil ghurm)". Kaidah ini melekat "hak memperoleh 
keuntungan" dengan "tanggungjawab menanggung kerugian" kaidah ini biasanya digunakan untuk mengusulkan preferensi terhadap instrumeninstrumen pembiayaan berbasis pembian laba rugi. Kaidah yang kedua adalah diperoleh dari sabda nabi "al-kharaj bil dhaman", yang menyatakan; manfaat dari satu hal adalah imbalan atas liabilitas karena menanggung kerugian dari hal tersebut" kaedah ini menegaskan bahwa pihak yang menikmati manfaat penuh suatu aset atau objek harus menanggung risikorisiko kepemilikan.

Kedua, risiko yang dilarang, dalam bentuk gharar eksesif. Gharar biasanya diterjemahkan sebagai ketidakpastian, risiko, atau bahaya, tetapi gharar juga mengimplisitkan ketidaktahuan, perjudian, kecurangan dan penipuan. Secara umum gharar berkaitan dengan ambiguitas dan/atau ketidaktahuan mengenai syarat-syarat kontrak ataupun objek kontrak. Dengan demikian suatu penjualan dapat dibatalkan (dinyatakan tidak sah) karena gharar, disebabkan risiko keberadaan dan risiko pengambilankepemilikan objek penjualan disatu sisi, serta risiko ketidakpastian mengenai kuantitas, kualitas, harga atau waktu pembayaran.

Risiko yang diperbolehkan, yaitu risiko yang tidak termasuk dalam dua kategori diatas, contoh-contoh risiko bentuk ini dapat berupa risiko operasional, risiko likuiditas dan lain-lain. Risiko-risiko ini dapat diterima ataupun dihindari. (Isra, 2015: 667).

Bank syariah menghadapi tantangan-tangan unik dalam bidang-bidang risiko antara lain; (Hennie Van Greuning dan Zamir Iqbal, 2011: 167).

1. Risiko komersial

Accounting and Auditing Organization of Islamic Institution (AAOIFI) mengidentifikasi risiko komersial sebagai risiko ketika bank syariah berada dalam tekanan untuk membayar ddeposan-investor pada tingkat pengembalian yang lebih tinggi dari yang harus dibayar seseuai dengan syarat sebenarnya dalam perjanjian investasi. Hal ini dapat terjadi ketika bank memiliki kinerja buruk dalam suatu periode dan tidak dapat menghasilkan keuntungan yang memadai untuk dibagikan kepada pemegang rekening.

2. Risiko Penarikan

Risiko penarikan yang barasal dari tekanan kompetitif yang dihadapi bank syariah dari bank syariah lain atau dari bank konvensional yang menyediakan unit usaha syariah. Bank syariah menghadapi risiko deposan yang menarik dana mereka jika menerima tingkat pengembalian yang lebih rendah dibandingkan yang bisa mereka terima dari bank lain. Jika bank syariah dikelola secara tidak efisien dan terus memberikan hasil yang rendah, maka akan pada akhirnya deposan akan memutuskan untuk memindahkan uang mereka dan mengikis nilai dari bank tersebut.

3. Risiko tata kelola

Pentingnya tata kelola dan risiko yang terkait denga tata kelola yang buruk baru-baru ini menarik perhatian dari para peneliti dan pembuat kebijakan. Risiko tata kelola megacu pada risiko yang timbul dari 
kegagalan dalam mengelola lembaga, kelalaian dalam melakukan usaha dan memenuhi kewajiban kontrak, serta kelemahan lingkungan kelembagaan internal dan eksternal, termasuk risiko hukum, dimana bank tidak dapat menegakkan perjanjian mereka.

4. Risiko Fidusia

Risikio fidusia adalah risiko yang timbul dari kegagalan suatu lembaga dalam mematuhi standar eksplisit dan implisit yang berlaku atas kewajiban fidusianya. Risiko fidusia mengarah pada risiko hukum jika bank melanggar tanggungjawab fidusianya terhadap deposan dan pemegang saham. Sebagai agen fidusia bank syariah diharapkan untuk bertindak berdasarkan kepentingan terbaik bagi deposan-investor dan pemegang saham. Jika dan ketika tujuan dari investor dan pemegang saham menyimpang dari kegiatan bank, maka bank akan menghadapi risiko fidusia.

5. Risiko Transparan

Transparan didefenisikan sebagai "keterbukaan publik atas informasi yang dapat dipercaya dan tepat waktu yang memungkinkan pengguna informasi untuk membuat penilaian yang akurat mengenai kondisi keuangan dan kinerja sebuah bank, kegiatan usaha, frofil risiko dan praktik manajemen risiko". Kurangnya transparan dapat menciptakan risiko kerugian akibat keputusan yang buruk berdasarkan informasi yang kurang lengkap atau tidak akurat. Kurangnya transparansi timbul dari dua sumber, penggunaan konvensi yang tidak baku dalam pelaporan perjanjian keuangan syariah dan kurangnya standar yang seragam dalam pelaporan antar bank.

6. Risiko Syariat

Risiko syariat terkait dengan struktur dan fungsi dari dewan syariah di tingkat lembaga dan sistemik. Risiko ini terdiri dari dua jenis, yang pertama dikarenakan oleh praktik non standar berkaitan dengan perjanjian yang berbeda di negara berbeda, dan kedua dikarenakan kegagalan dalam mematuhi syariat. Perbedaan dalam menerjemahkan syariat berdapak pada perbedaan dalam pelaporan keuangan, audit, dan perlakuan akuntansi. Hubungan antara bank dan deposan-investor tidak hanya sebagai agen dan penyedia pokok, melainkan juga didasari pada kepercayaan implisit antara keduanya bahwa agen akan menghormati keinginan penyedia pokok untuk mematuhi aturan syariat sepenuhnya. Hubungan ini membedakan perbankan syariah dari perbankan konvensional dan satu-satunya pembenaran bagi keberadaan perbankan syariah.

7. Risiko Reputasi

Risiki reputasi adalah risiko dimana perilaku yang tidak bertanggungjawab atau perilaku manajemen akan merusak kepercayaan dari klien-klien bank. Meskipun risiki fidusia dan syariat juga berasal dari kelalaian dan ketidakpatuhan, risiki reputasi adalah risiko dimana perilaku tidak bertanggungjawab dari satu lembaga dapat mencemari 
reputasi bank-bank lain dalam industri. Publisitas negatif dapat berdampak terhadap pangsa pasar, profitabilitas, dan likuiditas suatu lembaga. Risiko kepatuhan merupakan risiko disebabkan bank tidak mematuhi atau tidak melaksanakan peraturan perudang-undangan dan ketentuan yang berlaku. Pada praktiknya risiko kepatuhan melekat pada risiko bank yang terkait pada peraturan perundang-undangan dan ketentua lainnya yang berlaku, seperti risiko kredit terkait dengan ketentuan ketentuan kewajiban pemenuhan modal minimum, kualitas aktiva produktif, pembentukan penyisihan aktiva produktif, batas maksimum pemberian kredit, risiko pasar terkait ketentuan posisi devisa neto, risiko strategik terkait dengan rencana kerja dan anggaran tahunan bank, dan risko lainnya yang terkait dengan ketentuan-ketentuan tertentu. (Z. Dunil, 2004: 125).

\section{METODE PENELITIAN}

Adapun metode penelitian yang digunakan oleh penulis sebagai berikut:

1. Jenis dan Obyek penelitian

Penelitian ini sepenuhnya adalah riset perpustakaan (Library Risearch), yaitu penelitian yang kajiannya dengan menelusuri dan menelaah literatur - literatur dan penelitian yang difokuskan pada bahan-bahan pustaka. (Winarno Surahmat, 1995:251) Dalam hal ini obyek yang penulis maksudkan adalah buku-buku yang berkaitan dengan Risiko, dan Pembiayan bank syariah.

2. Sifat Penelitian

Penelitian ini bersifat deskriptik analitik yaitu, Pemecahan masalah yang diselidiki dengan menggambarkan/melukiskan keadaan subjek/objek penelitian (seseorang, lembaga, masyarakat dan lainlain) pada saat sekarang berdasarkan fakta-fakta yang tampak atau sebagaimana adanya. (Soejono \& H.Abdurrahman, 2005:23) Dalam hal ini penulis memaparkan dan menganalisis tentang Konsep Risiko dalam pembiayaan bank syariah ditinjauan dari sudut pandang ekonomi Islam.

3. Teknik Pengumpulan Data

Seperti yang telah dikemukakan bahwa penelitian ini adalah bersifat kepustakaan, maka pengumpulan data penulis membagi sumber menjadi dua bagian: Pertama, Sumber data primer, yaitu buku-buku yang mencakup tentang manajemen risiko dalam perbankan syariah. Kedua, Sumber data sekunder, yaitu mencakup referensireferensi lainnya yang berkaitan dengan tema pembahasan yang di maksud seperti terjemahan dan Tulisantulisan lain yang dianggap sesuai dengan tema yang dibahas.

4. Metode Analisis Data

Dalam menganalisa data penulis menggunakan metode: Metode Induktif, Yaitu metode yang berangkat dari fakta-fakta khusus, peristiwa-peristiwa yang khusus dan yang kongkret, kemudian dari fakta-fakta atau peristiwaperistiwa yang khusus itu di generalisasi sehingga mempunyai sifat umum. ( Sutrisno Hadi, 2004:41)Dalam hal ini penulis berusaha 
mempelajari tentang mashlahah dalam konsumsi dari sudut pandang ekonomi islam. agar dapar dibangun suatu sintesis yang berupa kesimpulan yang bersifat umum. Metode Deduktif, yaitu metode yang dipergunakan untuk mengambil kesimpulan mulai dari pernyataan yang bersifat umum menuju ke yang khusus yang menggunakan rasio atau penalaran (Nana Sudjana, 1991:7). Metode ini penulis gunakan untuk memahami data yang bersifat umum yang biasanya merupakan data yang bersifat dalil, seperti ayat-ayat alqur'an aupun hadist-hsdist Nabi Muhammad saw sehingga diharapkan dapat mengambil ketegasan menjadi sifat khusus.

Metode Content Analysis atau disebut dengan analisis isi, yaitu Metode penelitian yang dimanfaatkan untuk menarik kesimpulan yang reflikatif dan shahih dari data atas dasar konteksnya. (Soejono \& H. Abdurrahman, 2005:13) Dalam buku Metode Penelitian (Suatu Pemikiran dan Penerapan) Karangan Soejono S.H \& H. Abdurrahman S.H disebutkan Untuk menggunakan metode Content Analysis di perlukan tiga syarat yang di pakai dalam analisis isi yaitu Objektivitas, pendekatan sistematis dan generalisasi. (Soejono \& H.Abdurrahman, 2005:15) Dalam hal ini penulis menggunakan metode ini untuk menganalisa isi kajian yang berkaitan dengan tema yang dibahas.

\section{HASIL DAN PEMBAHASAN \\ Penyebab Terjadinya Risiko}

Risiko dalam konteks perbankan merupakan suatu kejadian potensial, baik yang dapat diperkirakan maupun yang tidak dapat diperkirakan yang berdampak negatif terhadap pendapatan dan permodalan bank. Untuk dapat menetapkan proses manajemen risiko, maka pada tahap awal bank harus secara tepat mengidentifikasi risiko dengan cara mengenal dan memahami seluruh risiko yang sudah ada maupun yang mengkin timbul dari suatu bisnis baru bank, termasuk risiko yang bersumber dari perusahaan terkait dengan afiliasi lainnya. (Veithzal Rivai et al., 2007: 792).

Risiko kredit muncul jika bank tidak bisa memperoleh kembali cicilan pokok dan atau bunga dari pinjaman yang diberikannya atau investasi yang sedang dilakukannya. Penyebab utama terjadinya risiko kredit adalah terlalu mudahnya bank memberikan pinjaman atau melakukan investasi karena terlalu dituntut untuk memanfaatkan kelebihan likuiditas, sehingga penilaian kredit kurang cermat dalam mengantisipasi berbagai kemungkinan risiko usaha yang dibiayainya. (Zainul Arifin, 2006: 225).

Risiko pembiayaan atau kredit merupakan risiko yang paling besar dampak dan potensi terjadinya, maka risiko pembiayaan pada perbankan memiliki perhatian paling spesial diantara jenis-jenis resiko lainnya. Dari risiko pembiayaan ini bisa berdampak pada risiko lain secara beruntun dan berkesinambungan, maka keberhasilan bank mengelola risiko pembiayaan akan berdampak positif pada keberlangsungan hidup sebuah bank. (Edi Susilo, 2017: 76). 
Risiko ini akan semakin tampak ketika perekonomian dilanda krisis atau resesi. Turunnya perjualan akan mengakibatkan berkurangnya penghasilan perusahaan, sehingga perusahaan mengalami kesulitan untuk memenuhi kewajiban membayar utang-utangnya. Ini akan diperberat dengan meningkatnya tingkat bunga. Ketika bank akan mengekseskusi kredit macetnya, bank tidak memperoleh hasil yang memadai, karena jaminan yang ada tidak sebanding dengan besarnya kredit yang diberikan.

\section{Penerapan kebijakan Manajemen Risiko}

Bank menerapkan kebijakan manajemen risiko yang bertujuan untuk memastikan risiki-risiko yang timbul dalam kegiatan usahanya dapat diidentifikasi, diukur, dikelola dan dilaporkan yang pada akhirnya akan memberikam manfaat berupa peningkatan kepercayaan pemegang saham dan masyarakat, memberikan gambaran lebih akuran mengenai kinerja dimasa mendatang termasuk kemungkinan kerugian yang akan terjadi dan meningkatkan metode dan proses pengambilan keputusan serta penilaian risiko dengan adanya ketersediaan informasi yang kini, yang dengan sendirinya meningkatkan kinerja dan daya saing bank.

Manajemen risiko merupakan aktivitas yang utama dari suatu bank sebagai lembaga intermediasi yang bertujuan untuk mengoptimalkan trade-off antara risiko dan pendapatan, dan untuk membantu merencanakan dan pembiayaan pengembangan usaha secara tepat, efektif, dan efisien.

Pengembangan kerangka yang lebih luas dalam hal pengelolaan risiko dilakukan dengan pembentukan satuan kerja manajemen risiko kantor pusat serta satuan kerja risiko regional. Saat ini satuan kerja manajemen risiko telah memastikan pelaksanaan proses manajemen risiko berjalan dengan lancar dan memberikan gambaran profil risiko kepada manajemen.

Tugas dari satuan kerja manajemen risiko sebagai berikut:

1. Memantau posisi risiko secara keseluruhan maupun perjenis risiko.

2. Melakukan pengkajian risiko atas usulan aktivitas dan produk baru.

3. Melakukan pengkajian atas sistem prosedur baru.

4. Memantau risiko yang timbul sebagai akibat terjadinya penyimpangan terhadap prosedur kerja.

5. Melakukan analisis sentivitas terhadap perubahan faktor risiko.

6. Menyusun dan menyampaikan laporan profil risiko kepada direksi dan komite pemantau risiko. (Veithzal Rivai dan Rifki Ismal , 2013: 238).

Ada empat tahap dalam menganalisis kadar pengawasan risiko yaitu:

1. Membangun pengawasan risiko, pengawasan yang harus dibangun untuk mengeliminasi hazard dan mengurangi risiko. Ketika pengawasan risiko dibangun, maka risiko dievaluasi sampai ia dapat dikurangi hingga ketingkat dimana manfaatnya lebih banyak daripada biaya potensial.

2. Mengidentifikasi pengawasan risiko, pembangunan pengawasan risiko diawali dengan pengambilan tingkat risiko yang ditentukan sebelumnya, dan mengidentifikasi sebanyak mungkin pilihan pengawasan risiko yang 
mungkin diambil bagi semua hazard yang melampaui tingkat risiko yang bisa diterima.

3. Menentukan efektifitas risiko, setelah identifikasi pilihan pengawasan risiko, proses berikutnya adalah menentukan efek dari setiap pengawasan yang berkaitan dengan hazard.

4. Memilih pengawasan risiko, pengawasan terbaik adalah yang konsisten dengan tujuan operasional dan penggunan sumber daya yang tersedia secara optimal. (Zainul Arifin, 2006: 232).

Esensi dari penerapan manajemen risiko adalah kecukupan prosedur dan metodologi pengelolaan risiko sehingga kegiatan usaha bank tetap dapat terkendali pada batas/limit yang dapat diterima serta menguntungkan bank. Namun demikian mengingat perbedaan kondisi pasar, struktur, ukuran serta kompleksitas usaha, maka tidak terdapat satu sistem manajemen risiko yang universal untuk seluruh bank sehingga setiap bank harus membangun sistem manajemen risiko sesuai dengan fungsi dan organisasi manajemen risiko pada bank. Manajemen risiko dibutuhkan untuk mengidentifikasi, mengukur, dan mengendalikan berbagai macam risiko, karena itu menjadi alat yang sangat mendasar untuk mendukung keberlangsungan usaha bank. (Veithzal Rivai dan Arviyan Arifin, 2010: 943).

\section{Optimalisasi Peran Dewan Pengawas Syariah}

Dewan Pengawas Syariah (DPS) memiliki peran penting dan strategis dalam penerapan prinsip syariah di Perbankan Syariah. DPS bertanggung jawab untuk memastikan semua produk dan prosedur bank syariah sesuai dengan prinsip syariah. Karena pentingnya peran DPS ini, maka dua undang-undang di Indonesia mencantumkan keharusan adanya Dewan pengawas syariah di perusahaan syariah dan lembaga perbankan syariah, yaitu Undang-Undang UU No. 40 Tahun 2007 tentang Perseroan Terbatas dan UU No. 21 Tahun 2008 tentang Perbankan Syariah. Dengan demikian, secara yuridis, Dewan Pengawas Syariah (DPS) di lembaga perbankan menduduki posisi yang kuat, karena keberadaannya sangat penting dan strategis.

Menurut Undang-undang No 40 Tahun 2007 tentang Perseroan pasal 109 disebutkan bahwa:

1. Perseroan yang menjalankan kegiatan usaha berdasarkan prinsip syariah selain mempunyai Dewan Komisaris wajib mempunyai Dewan Pengawas Syariah.

2. Dewan Pengawas Syariah sebagaimana dimaksud pada ayat (1) terdiri atas seorang ahli syariah atau lebih yang diangkat oleh RUPS atas rekomendasi Majelis Ulama Indonesia.

3. Dewan Pengawas Syariah sebagaimana dimaksud pada ayat (1) bertugas memberikan nasihat dan saran kepada Direksi serta mengawasi kegiatan Perseroan agar sesuai dengan prinsip syariah. (Undang-undang No. 40 Tahun 2007).

Berdasarkan undang-undang tersebut, setiap perusahaan yang berbadan hukum Perseroan Terbatas wajib mempunyai Dewan Pengawas Syariah. 
Sejalan dengan itu, undang-undang No 21 Tahun 2008 Pasal 32 menyebutkan :

1. Dewan Pengawas Syariah wajib dibentuk di Bank Syariah dan Bank Umum Konvensional yang memiliki UUS.

2. Dewan Pengawas Syariah sebagaimana dimaksud pada ayat (1) diangkat oleh Rapat Umum Pemegang Saham atas rekomendasi Majelis Ulama Indonesia.

3. Dewan Pengawas Syariah sebagaimana dimaksud pada ayat (1) bertugas memberikan nasihat dan saran kepada direksi serta mengawasi kegiatan bank agar sesuai dengan Prinsip Syariah.

4. Ketentuan lebih lanjut mengenai pembentukan Dewan Pengawas Syariah sebagaimana dimaksud pada ayat (1) diatur dengan Peraturan Bank Indonesia.

Dewan Pengawas Syariah (DPS) adalah badan independen yang terdiri dari para pakar syariah muamalah yang juga memiliki pengetahuan dalam bidang perbankan yang ada di lembaga keuangan syariah dan bertugas mengawasi pelaksanaan keputusan DSN pada lembaga keuangan syariah tersebut. Dewan Pengawas Syariah merupakan badan independen, sehingga untuk menjamin mengeluarkan pendapat maka harus diperhatikan beberapa hal:

1. Dewan Pengawas Syariah bukan staf bank, dalam arti bahwa mereka tidak tunduk dibawah kekuasaan administratif

2. Dewan Pengawas Syariah dipilih oleh Rapat Umum Pemegang Saham

3. Honorarium DPS ditentukan oleh Rapat Umum Pemegang Saham

4. Dewan Pengawas Syariah mempunyai sistem kerja dan tugas-tugas tertentu seperti halnya Badan Pengawas lainnya. (Karnaen Perwataatmadja dan Muhammad Syafii Antonio, 1992: 3).

Berdasarkan keputusan Pimpinan MUI tentang susunan pengurus DSN-MUI No:Kep-98/MUI/III/2001, Dewan Pengawas Syariah menjalankan fungsifungsi sebagai berikut:

1. Sebagai penasihat dan pemberi saran kepada direksi, pimpinan kantor cabang syariah mengenai hal-hal yang berkaitan dengan aspek syariah.

2. Sebagai mediator antara bank dengan Dewan Syariah Nasional (DSN) dalam mengomunikasikan usul dan saran pengembangan produk dan jasa bank memerlukan kajian dan fatwa dari DSN.

3. Sebagai perwakilan DSN yang ditempatkan pada bank-bank syariah.

Tugas Dewan Pengawas Syariah (DPS), antara lain :

1. Mengawasi jalannya lembaga keuangan syariah sehari-hari agar senantiasa sesuai dengan ketentuan-ketentuan syariah

2. Membuat pernyataan secara berkala bahwa lembaga keuangan syariah yang diawasinya telah berjalan sesuai dengan ketentuan syariah

3. Meneliti dan membuat rekomendasi produk baru dari lembaga keuangan syariah yang diawasinya.

4. Bersama Komisaris dan Direksi mengawal dan menjaga penerapan nilainilai Islam dalam setiap aktivitas yang dilakukan oleh lembaga keuangan syariah. 
5. Melakukan sosialisasi kepada masyarakat tentang lembaga keuangan syariah melalui media-media yang sudah ada dan berlaku di masyarakat. Jenis manajemen risiko yang terkait erat dengan peran DPS adalah risiko reputasi yang selanjutnya berdampak pada displaced commercial risk, seperti risiko likuiditas dan risiko lainnya. Shanin A. Shayan menyatakan bahwa risiko terbesar menghadapi sistem keuangan global bukanlah kesalahan tentang kemampuan menciptakan laba, tetapi yang lebih penting adalah kehilangan kepercayaan dan kredibilitas tentang bagaimana perasional kerjanya. Peran DPS perlu dioptimalkan agar mereka bisa memastikan segala produk dan sistem operasional bank Islam benar-benar sesuai dengan Islam. Fungsi dan peran DPS di bank Islam memiliki relevansi yang kuat dengan manajemen risiko perbankan Islam, yakni risiko reputasi, yang selanjutnya berdampak pada risiko lainnya seperti risiko likuiditas. Pelanggaran Islam Complience yang dibiarkan atau luput dari pengawasan DPS akan merusak citra dan kredibilitas bank Islam dimata masyarakat sehingga dapat menurutkan kepercayaan masyarakat kepada bank Islam.

\section{SIMPULAN}

Risiko dapat didefenisikan sebagai "keberadaan ketidakpastian tentang hasil di masa mendatang". Risiko berkaitan dengan kasus-kasus ketika probabbilitas objektif atau probabilitas subjektif dapat ditentukan pada hasil potensial, sehingga memungkinkan untuk kuantifikasi. Ketidakpastian merujuk pada kasus ketidaktahuan secara penuh tentang hasil apapun yang potensial terjadi, sehingga membuat tidak mungkin dilakukan kuantifikasi maupu pengambilan keputusan yang rasional. Hassan mengidentifikasi tiga tipe risiko dari perspektif Islam, Pertama, risiko esensial yang inheren di dalam semua transaksi bisnis. Kedua, risiko yang dilarang, dalam bentuk gharar eksesif. Ketiga Risiko yang diperbolehkan, yaitu risiko yang tidak termasuk dalam dua kategori diatas, contoh-contoh risiko bentuk ini dapat berupa risiko operasional, risiko likuiditas dan lain-lain.

Penyebab utama terjadinya risiko kredit adalah terlalu mudahnya bank memberikan pinjaman atau melakukan investasi karena terlalu dituntut untuk memanfaatkan kelebihan likuiditas, sehingga penilaian kredit kurang cermat dalam mengantisipasi berbagai kemungkinan risiko usaha yang dibiayainya. Manajemen risiko dibutuhkan untuk mengidentifikasi, mengukur, dan mengendalikan berbagai macam risiko, karena itu menjadi alat yang sangat mendasar untuk mendukung keberlangsungan usaha bank. Jenis manajemen risiko yang terkait erat dengan peran DPS adalah risiko reputasi yang selanjutnya berdampak pada displaced commercial risk, seperti risiko likuiditas dan risiko lainnya. Fungsi dan peran DPS di bank Islam memiliki relevansi yang kuat dengan manajemen risiko perbankan Islam, yakni risiko reputasi, yang selanjutnya berdampak pada risiko lainnya seperti risiko likuiditas. 


\section{DAFTAR PUSTAKA}

Adiwarman Karim, (2006). Bank Islam: Analisis Fiqih dan Keuangan, Jakarta: PT. RajaGrafindo Persada.

Ascarya, (2011). Akad dan Produk Bank Syariah, Jakarta: PT. RajaGrafindo Persada.

Edi Susilo, (2017). Analisis Pembiayan dan Risiko Perbankan Syariah, Yogyakarta: Pustaka Pelajar.

H. Abdurrahman \& Soejono, (2005). Metode Penelitian, Jakarta: PT Rineka Cipta.

Hennie Van Greuning \& Zamir Iqbal, (2011). Analisis risiko Perbankan Syariah, Jakarta: Salemba Empat.

Isra, (2015). Sistem Keuangan Islam; Prinsip dan Operasi, Jakarta: Rajawali Press.

Karnaen Perwataatmadja \& H. Muhammad Syafii Antonio, (1992). Apa dan Bagaimana Bank Islam, Yogyakarta: PT Dana Bhakti Prima Yasa.

Muhammad, (2005). Manajemen Bank Syariah, Yogyakarta: AMP YKPN.

Muhammad, (2009). Model-model Akad Pembiayaan di Bank Syariah, Yogyakarta: UII Press.

Muhammad, (2005). Manajemen Pembiayaan Bank Syariah, Yogyakarta: UPP AMP KYPN.

Nana Sudjana, (1991). Teori-Teori Belajar Untuk Pengajaran, Jakarta : FEUI Sutrisno Hadi, (2004). Metodologi Research 2, Yogyakarta: Andi Offset.

Undang-undang No.40 Tahun 2007 Tentang Perseroan Terbatas

Undang-undang Nomor 10 tahun 1998 tentang Perubahan atas UU Nomor 7 tahun 1992 tentang Perbankan

Veithzal Rivai \& Andria Permata Veithzal, (2008). Islamic Financial Management, Jakarta: PT. RagaGrafindo Persada.

Veithzal Rivai \& Arviyan Arifin, (2010). Islamic Banking; Sebuah Teori, Konsep dan Aplikasi, Jakarta: Bumi Aksara.

Veithzal Rivai, dkk, (2007). Bank and Finacial Institution Management; Conventional \& Sharia System, Jakarta: PT RajaGrafindo Persada.

Veithzal Rivai \& Rifki Ismal, (2013). Islamic Risk Management For Islamic Bank, Jakarta: PT Gramedia Pustaka Utama.

Zainul Arifin, (2006). Dasar-dasar Manajemen Bank Syariah, Jakarta: Pustaka Alvabet.

Z. Dunil, (2004). Kamus Istilah Perbankan Indonesia, Jakarta: PT Gramedia Pustaka Utama. 